\title{
Determinants of cross-border merger premia
}

\author{
Ralph Sonenshine $\cdot$ Kara Reynolds
}

Published online: 17 July 2013

(C) Kiel Institute 2013

\begin{abstract}
Firms have a broad range of rationales for engaging in cross-border mergers and other forms of foreign direct investment (FDI); while some companies are in search of the cost advantages provided by foreign resources, other firms are primarily interested in gaining access to new markets. Although a significant amount of research has explored the patterns of FDI, little work has been done to assess what influences the value of cross-border mergers and, in particular, what determines why some cross-border mergers are expected to result in higher synergies when compared to others. This paper explores what characteristics of a merger are expected to increase the synergies that a firm will accrue from a cross-border merger by testing how a variety of factors impact the premia paid to effectuate a cross-border merger. We find that firms are willing to pay a higher premium to obtain greater control over foreign firms, and that this control is even more important in mergers involving firms in emerging markets. We also find that the factors affecting deal premia in cross-border mergers differ based on whether the acquirer has a high or low intangible asset intensity level.
\end{abstract}

Keywords Cross-border mergers $\cdot$ FDI $\cdot$ Premia $\cdot$ Intangible asset $\cdot$ Synergies

JEL Classification G34

R. Sonenshine $(\bowtie) \cdot K$. Reynolds

Department of Economics, American University, 4400 Massachusetts Avenue,

NW, Washington, DC 20016, USA

e-mail: Sonenshi@american.edu

K. Reynolds

e-mail: reynolds@american.edu 


\section{Introduction}

Cross-border mergers have grown rapidly over the past decade due to a variety of factors including industry consolidation, privatization, and the liberalization of economies (Shimizu et al. 2004). While most cross-border mergers take place among firms in developed countries, an increasing amount of activity has been occurring in emerging markets. This is not surprising considering that the developing world has accounted for much of the world's economic growth over the past decade; the OECD recently predicted that developing and emerging economies are likely to account for $60 \%$ of the world's economy by 2030 (OECD 2010). Although there has been a significant amount written examining the welfare effects of cross-border mergers, few papers have explored how the expected synergies from a cross-border merger may differ between mergers among firms in developing versus developed countries.

Companies choose to engage in cross-border mergers for a variety of reasons including improved market access, cost advantages (e.g., lower labor costs and/or lower trade barriers), and regulatory, corporate, or tax differences. At times there may be multiple explanations for cross-border mergers depending on the industry, time period, and location of the acquirer and target. This paper hypothesizes that the deal premium, which is the percent difference between the price paid to effectuate the merger and the current market price of the target firm, represents the expected benefit or synergies that the acquiring firm expects to gain from undertaking the merger. We explore the primary reasons why firms engage in cross-border mergers by exploring the key determinants of deal premia, and whether these determinants differ in mergers involving firms in emerging markets when compared to others.

We are particularly interested in whether firms are willing to pay more to obtain a greater level of control over their foreign acquisition, and whether this control is more important when the acquisition is in an emerging market. A number of researchers, such as Grossman and Hart (1986), have shown theoretically that there is a large benefit to acquiring control over another firm's assets, especially when it is costly to write or enforce contracts; to the extent that contracts are more difficult to enforce in emerging markets, one would expect that firms would place a higher premium on control of firms in emerging markets. Indeed, we find that firms are willing to pay a higher premium in order to obtain greater control over their foreign acquisition, and that the value of this control is even higher in mergers involving firms in emerging markets. Although one might expect that control would be more important for firms with high levels of intangible assets which would be difficult to protect in countries with weak intellectual property laws, we find that ownership is more important in emerging markets when compared to other countries regardless of the value of intangible assets held by the acquiring firm. This paper is organized as follows: the next section reviews the relevant literature and empirical studies. Section 3 discusses our empirical approach and dataset, along with some descriptive statistics. Section 4 contains our main results, and Sect. 5 concludes. 


\section{Literature review}

Since Hymer (1960), researchers have argued that foreign direct investment (FDI) results from multinationals seeking to exploit their superior knowledge and scale by pursuing new markets. Industrial organization explanations for FDI typically involve multinational organizations taking advantage of the existence of imperfect competition or other market imperfections in foreign countries using their specialized resources and superior technology and management. ${ }^{1}$ A multinational may choose to engage in cross-border mergers to internalize an activity in order to avoid the disadvantages of working through a foreign firm. Cross-border mergers also enable firms to obtain resources from local firms, such as its knowledge base, technology, and human resources, as well as gain access to markets and to key constituencies at the local level. In this section, we review recent research most directly related to our empirical analysis.

Many of the empirical studies of cross-border mergers analyze the determinants of the wealth the cross-border merger creates for shareholders of the acquiring firms. Specifically, these empirical studies analyze the differential determinants of the cumulative abnormal returns that accrue to the stock holders of the acquiring firm following the announcement of a merger, implicitly studying the factors investors deem to be the most important. For example, Markides and Ittner (1994) analyze the returns to the stockholders of U.S. firms engaging in international acquisitions between 1975 and 1988 to find that the value created by a cross-border merger is a function of such things as the type of acquisition and the level of advertising undertaken by the acquiring firm. Similarly, Morck and Yeung (1992), find that the abnormal returns of acquirers increase with the value of information based assets held by the firm.

In contrast, we analyze the determinants of the deal premium (how much the acquiring firm is paying for the target firm over and above current market value), implicitly studying the factors an acquiring firm's management and board of directors believe will increase the synergies that will result from the cross-border merger. To the degree to which management has a better understanding of how to evaluate the benefits of a particular merger, we would expect this dependent variable to give us a better understanding of the value of these cross-border mergers. Several papers attempt to analyze this issue by studying the cumulative abnormal returns accruing to shareholders of the target firms, particularly in the United States. For example, Harris and Ravenscraft (1991) confirm their hypothesis that firms with high levels of intangible assets or research and development (R\&D) intensity are natural candidates for cross-border mergers because the combined firm needs to spread the high fixed cost of R\&D expenditures and knowledge asset attainment over large foreign markets. ${ }^{2}$ They also find that differences in government and regulatory policies, as well as imperfections and information asymmetries in capital markets, will impact the expected synergies that will stem from a

\footnotetext{
${ }^{1}$ See Cebenoyan et al. (1992), Hymer (1960), Vernon (1966), Kindleberger (1984), Caves (1982), Buckley and Casson (1976), Magee (1976) and Dunning and Rugman (1985).

2 A number of other papers have also emphasized the importance of intangible assets in determining the value of a cross-border merger. Vermuelen and Barkema (2001), for example, find in their examination of the mode of entry used for international expansion by Dutch firms that the firms most likely to engage cross-border mergers were those whose goal was to expand the knowledge base of the firm.
} 
cross-border merger. The results in Kuipers et al. (2009) confirm many of these results using a later sample period, concluding that the returns accruing to the shareholders of U.S. targets are primarily a function of deal-specific and firm-specific effects.

In this paper, we are most interested in the hypothesis suggested by a number of authors that firms primarily engage in cross-border mergers versus other forms of FDI to gain control over assets (Newburry and Zeira 1997), particularly due to difficulties writing or enforcing complete contracts. ${ }^{3}$ In a comprehensive review of case studies of foreign acquisitions, Moran (2001) finds that the acquisition of corporate control is a key determinant of shareholder wealth gains, particularly in the presence of proprietary assets. ${ }^{4}$ This hypothesis is studied in Chari et al. (2010), which analyzes the cumulative abnormal returns accruing to shareholders of the acquiring firms in 3,118 cross-border mergers between 1986 and 2006. The authors find that control (as measured by percent ownership following the deal) is only important in emerging market mergers, not in mergers in which the target is headquartered in the United States or Japan.

Like Chari et al. (2010), we analyze the value of control in cross-border mergers, and specifically study whether this control is more valuable in mergers with firms in emerging markets or in mergers with firms with high levels of intangible assets. Chari et al. (2010) implicitly study the degree to which the market expects the cross-border merger to increase the value of the acquiring firm by using the cumulative abnormal return accruing to the acquiring firm's shareholders. We are more interested in studying to what degree control is important to the firm's management, who should have a more accurate understanding of the expected synergies that will be created by the merger. To do this, we follow Weitzel and Berns (2006) and analyze the determinants of the deal premium, the percent difference between the final bid price of the acquirer over the market value of the target before the merger. As explained in Weitzel and Berns (2006), the final bid price includes both the pre-merger market value of the target and the target's share of the incremental net present value of the expected joint merger synergies, or the added value associated with the combined business.

\section{Data and empirical methodology}

This paper analyzes a set of 848 completed cross-border mergers of public companies with a minimum transaction value of $\$ 250$ million that were announced over an eleven year time period between January 1, 2000 and December 31, 2010. ${ }^{5}$ We collected detailed data on each merger from the Thomson SDC database.

Table 1 shows the distribution of cross-border mergers between developing and developed countries. As eluded to in the introduction, most cross-border mergers

\footnotetext{
${ }^{3}$ See also Coase (1937), Klein et al. (1978), Grossman and Hart (1986) and Williamson (1979).

${ }^{4}$ Moran (2001) finds that the impact of control is minimal in labor-intensive industries with limited intangible asset.

5 The $\$ 250$ million transaction value is admittedly somewhat restrictive. For example, if the threshold was lowered to $\$ 100$ million in deal value, then the data set would consist of 1,130 transactions, while if there were no deal threshold, the data set would consist of 2,154 transactions. Specifications that include only larger mergers (those with deal values above $\$ 300$ and $\$ 500$ million) were qualitatively similar to those presented here. However, our results may not hold for relatively small transactions.
} 
Table 1 Distribution of cross-border mergers

Table 2 Cross-border mergers by country of target and acquiring firm

\begin{tabular}{llc}
\hline & \multicolumn{2}{l}{ Country of target firm } \\
\cline { 2 - 3 } & Developing & Industrialized \\
\hline Country of acquiring firm & & \\
Developing & $35(4 \%)$ & $38(5 \%)$ \\
Industrialized & $79(9 \%)$ & $696(82 \%)$ \\
\hline
\end{tabular}

\begin{tabular}{lcllc}
\hline \multicolumn{1}{l}{ Country of target firm } & & & \multicolumn{2}{l}{ Country of acquiring firm } \\
\cline { 1 - 1 } \cline { 5 - 6 } Country & $\begin{array}{l}\text { Share } \\
\text { of total }\end{array}$ & & Country & $\begin{array}{c}\text { Share } \\
\text { of total }\end{array}$ \\
\hline United States & 28.7 & & United States & 17.2 \\
United Kingdom & 9.4 & & United Kingdom & 12.0 \\
Canada & 8.6 & & France & 8.8 \\
Australia & 5.5 & & Germany & 7.0 \\
Netherlands & 3.5 & & Canada & 6.6 \\
Germany & 3.1 & & Spain & 4.5 \\
Norway & 2.6 & & Switzerland & 4.5 \\
Sweden & 2.6 & & Netherlands & 4.2 \\
France & 2.4 & & Italy & 3.3 \\
Switzerland & 2.0 & & Japan & 3.7 \\
Greece & 1.8 & & Australia & 3.3 \\
Other & 29.8 & & Other & 24.9 \\
\hline
\end{tabular}

take place between industrialized countries. Our dataset indicates that between 2000 and 2010, $82 \%$ of cross-border mergers took place between firms that both resided in industrialized countries. In fact, just over $46 \%$ of all cross-border mergers involved the acquisition of a firm within just three countries: the United States, the United Kingdom, and Canada as detailed in Table 2. Similarly, we see from Table 2 that acquiring firms within the United States, United Kingdom and France accounted for $38 \%$ of all cross-border mergers during our sample period.

A much smaller number of cross-border mergers involve firms in developing countries. ${ }^{6}$ As indicated in Table $1,9.3 \%$ of mergers in our sample involved a firm in an industrialized country acquiring a company in a developing country, while the reverse occurred in $4.5 \%$ cases. Just $4.1 \%$ of the cross-border mergers in our sample involved two firms residing in developing countries. Not a single developing country ranked among the top 10 countries involved in cross-border mergers shown in Table 2. Brazil, India and South Africa accounted for $34.2 \%$ of all firms acquired in developing countries during our sample period, while Brazil, China and Mexico accounted for about $46 \%$ of the firms in developing countries that chose to acquire foreign firms.

These figures are slightly misleading, however, because a greater percentage of the mergers involving firms in developing countries occurred over the past 5 years.

\footnotetext{
${ }^{6}$ We use the World Bank's definition of developing versus developed regions.
} 


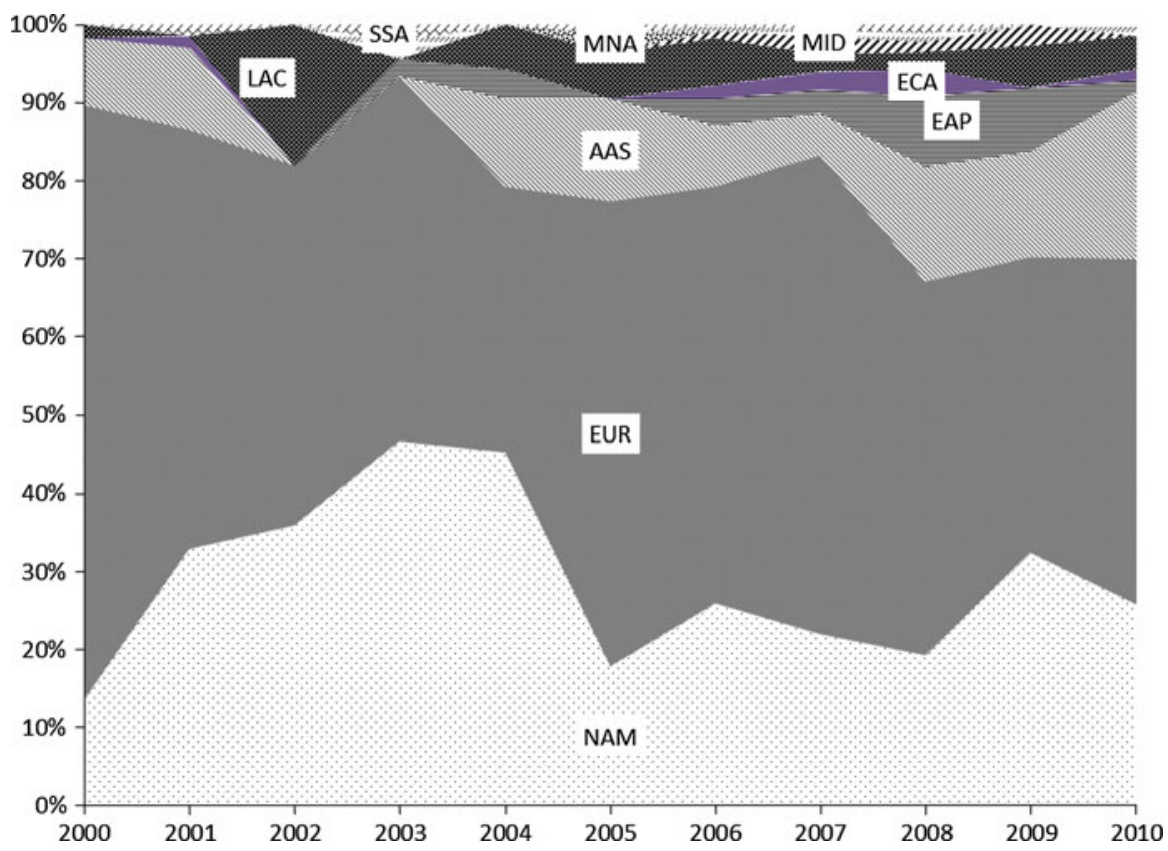

Fig. 1 Annual distribution of cross-border mergers by region of the acquirers. Developing regions include East Asia and Pacific (includes China and Indonesia) (EAP), East Europe and Central Asia (includes Turkey and Russia) (ECA), Latin America and Caribbean (includes Brazil and Mexico) (LAC), Middle East and North Africa (includes Egypt) (MNA), South Asia (includes India) (SAS), and SubSahara Africa (includes Nigeria and South Africa) (SSA). Developed regions include Austral Asia (includes Australia, Japan, and South Korea) $(A A S)$, Western Europe (includes France, UK, and Germany) (EUR), Middle East (MID), and North America (includes Canada and USA) (NAM)

Figures 1 and 2 show the distribution of mergers over time by region. There has been a large increase in mergers involving the acquisition of firms in Asia, Latin America and the Caribbean, and Eastern Europe. These regions accounted for only $2 \%$ of the acquisitions in 2000 versus over $18 \%$ in the years between 2008 and 2010. In contrast, Western Europe accounted for $76 \%$ of the acquirers and $42 \%$ of the targets in 2000 but only 44 and $17 \%$ of the acquirers and targets in 2010. The distribution of targets and acquirers (except for the year 2000) in North America remained fairly stable over the 11 year period.

This paper assesses the factors that influence the deal premium in cross-border mergers, which should give us some indication of what factors are expected to increase the synergies (or expected benefits) that a firm will earn from engaging in the cross-border merger. For each cross-border merger, we calculate the deal premium as the percent difference between the stock price paid to effectuate the merger at the announcement date and the stock price 4 weeks prior to the merger announcement. We chose to use a 4 week time period instead of a smaller window to account for the possibility that information regarding the merger can leak into the market prior to the announcement date. Assuming the local stock markets are efficient, or all available public information is accounted for in the current stock 


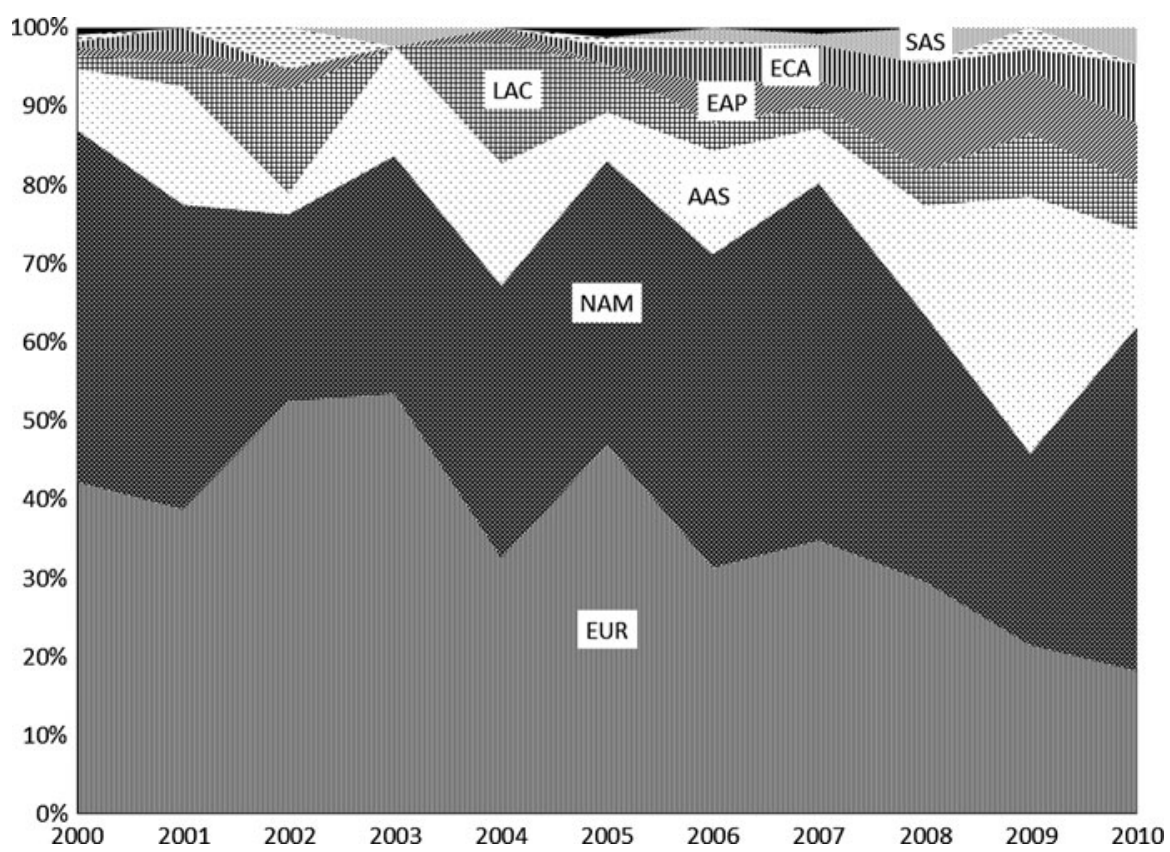

Fig. 2 Annual distribution of cross-border mergers by region of the target. Developing regions include East Asia and Pacific (includes China and Indonesia) (EAP), East Europe and Central Asia (includes Turkey and Russia) (ECA), Latin America and Caribbean (includes Brazil and Mexico) (LAC), Middle East and North Africa (includes Egypt) (MNA), South Asia (includes India) (SAS), and Sub-Sahara Africa (includes Nigeria and South Africa) (SSA). Developed regions include Austral Asia (includes Australia, Japan, and South Korea) (AAS), Western Europe (includes France, UK, and Germany) (EUR), Middle East $(M I D)$, and North America (includes Canada and USA) (NAM)

price, the target firm must be worth at least the value of the deal premium over and above market value to the acquiring firm. All of the firms in the data set are public, so the purchase price captures the full return to the shareholders of the target firm. ${ }^{7}$ The stock price as expressed in the deal value can be paid in any or all of the following: cash, acquirer stock, or debt assumption. In any of the deal financing methods, the stock price captures the returns to the target shareholders.

We examine key firm, deal, industry, and country characteristics to test their effect on the deal premium using a linear regression. ${ }^{8}$ Our key variable of interest is the percent of ownership of the foreign entity being acquired in the transaction. As discussed in the literature review, acquiring more control of a firm may add value to

\footnotetext{
${ }^{7}$ One possible source of mis-measurement in this variable could be deal renegotiation. The data set only includes accepted mergers, but it is possible that a new merger price could occur at a later time. This could occur if issues occur during due diligence that detract or potentially add to the value of the deal. A renegotiated deal value could bias the deal premium up or down. However, we believe it is unlikely that deal renegotiations would have a significant effect on the data set, since the data set consists of consummated mergers.

${ }^{8}$ There are admittedly other firm and deal characteristics that could also be considered, such as the presence of multiple bidders or the method of financing (cash versus stock). These variables were not included due to data limitations.
} 
the merger in situations where there are difficulties writing or enforcing complete contracts. Note that firms purchased $100 \%$ of the foreign firms in roughly half of our sample.

To test the robustness of the value of control, we also include a number of important control variables that other studies have found to be important determinants of the value of cross-border mergers. Two key firm characteristics we employ are the intangible asset intensity ratio, both for the acquirer and the target. Intangible assets include intellectual property, such as patents and customer lists, and competitive intangible assets, such as know-how, management techniques, and customer service which derive from organizational learning and human capital within the firm. Firms report intangible assets as a separate line item on their balance sheet, and we calculate the intangible asset intensity by dividing reported intangible assets by the sales amount for the year prior to the merger. While the coefficient on intangible asset intensity of the acquiring firm captures to what extent firms engage in cross-border mergers to leverage their own knowledge assets, the coefficient of the intangible asset intensity of the target captures to what extent firms engage in mergers to gain access to the intellectual property of the target.

We include four important characteristics of the specific deal (merger) that should have a significant impact on the deal premium. In accordance with previous studies, we expect the deal value to have a negative effect on the deal premium while relative sales ratio (target divided by acquirer sales) to have a positive impact on the deal premium. ${ }^{9}$ Intuitively, large merger transactions involve a high level of asset duplication, which reduces the deal premium. In contrast, when there is significant difference in size between the acquirer and target, there is minimal asset duplication, so premia are higher.

The final deal specific variable (Challenged) we include is a dummy variable that indicates whether antitrust authorities sought to stop or restructure the merger due to concentration or other market power concerns. Industry concentration and market power have been shown to affect the deal premia paid to effectuate a merger. Both Markides and Ittner (1994) and Datta and Puia (1995) find that industry concentration has a positive and significant impact on the acquirer's abnormal returns. Sonenshine (2010) found in his study of mergers challenged by the U.S. government for potential antitrust violations that higher premia were paid when the merger was challenged, though interestingly lower than average premia were paid when market concentration was extremely high. Like these studies, we expect companies to pay a higher premium to acquire firms when there are substantial, expected market power gains from the merger. As such, our hypothesis is that the antitrust challenge will have a positive, significant effect on the deal premium. However, it is conceivable that companies may offer a lower premium to effectuate a merger that would be challenged as the legal process might result in additional costs as well as some firm restructuring.

The only industry-related variable (Related) we include is a dummy variable indicating whether the merger took place between firms within the same primary four-digit Standard Industrialized Classification (SIC) industry. A number of

\footnotetext{
9 See Sonenshine (2010).
} 
authors have hypothesized that there may be higher potential synergies from a crossborder merger of firms within the same industry, although the empirical results have not been conclusive. While Markides and Ittner (1994) and Marr et al. (2006) showed industry relatedness to have a positive, significant effect on shareholder value, Datta and Puia (1995) did not find a significant effect.

The remaining explanatory variables in our analysis include characteristics of the home country of the target and acquiring firm. For example, we believe that companies may be willing to pay more to control firms in countries with weak intellectual property rights protection because it will be much more difficult to protect the firm's intangible assets in those countries. To account for this possibility, we include the Ginarte and Park Index of intellectual property from Park (Park 2008). This index, which ranges from 0 to 5 , is an unweighted sum of five separate scores for intellectual property laws in the country. Scores are given for the country's IP law coverage (inventions that are patentable); membership in international treaties; duration of protection; enforcement mechanisms; and restrictions (for example, compulsory licensing in the event that a patented invention is not sufficiently exploited). Note that the index does not measure the enforcement of these laws.

A number of studies (Harris and Ravenscraft 1991; Swenson 1993; Dewenter 1995; Froot and Stein 1991) have found evidence that the exchange rate can be a significant determinant of the final price that a foreign company will pay for their acquisition. Intuitively, an appreciation of the acquiring firm's exchange rate will reduce the costs of acquiring a foreign target, thus increasing the price that the foreign acquirer may be willing to pay. We include the real effective exchange rate index ${ }^{10}$ for both the target and acquirer. This variable is used to control for the purchasing power of the acquirer and target and to indicate whether it is becoming more or less expensive to invest in the target country.

Foreign firms may gain more from acquiring firms in countries that would be relatively expensive to serve through international trade. To capture this possibility, we include the average tariff rate (across all products in a given year) in the country of the target firm, along with the distance between the capital cities of home countries of the merging companies, and whether or not the two countries share a contiguous border. Firms may benefit more from merging with companies that come from a common cultural background, thus we include whether the home countries of the merging companies share a common language between the two countries and whether those countries had a colonial relationship at any point since 1945. Finally, we include the populations of the acquirer and target countries; we believe that firms may gain more from merging with firms located in large markets. Population levels are used as a proxy for market size.

The regression includes year dummies to control for variations in the business cycle. Summary statistics for the full sample are given in Table 3. The average deal premium for the entire sample was nearly $35 \%$, but this premium varied

\footnotetext{
${ }^{10}$ Measured by the nominal effective exchange rate (the value of a currency against a weighted average of several foreign currencies) divided by a price deflator or index of costs, in which 2005 is the base year. This variable was provided by the World Bank's World Development Indicator. See http://data.worldbank.org/indicator/PX.REX.REER.
} 
Table 3 Summary statistics

\begin{tabular}{|c|c|c|c|c|}
\hline Variable & Mean & $\begin{array}{l}\text { Standard } \\
\text { deviation }\end{array}$ & Min & Max \\
\hline Deal premium & 0.349 & 0.551 & -0.999 & 12.77 \\
\hline Related & 0.438 & 0.496 & 0.000 & 1.000 \\
\hline Percent ownership & 0.730 & 0.3349 & 0.003 & 1.000 \\
\hline Deal value (billions) & 2.347 & 4.872 & 0.250 & 74.55 \\
\hline Sales ratio & 1.012 & 9.514 & 0.000 & 199.8 \\
\hline Intangible asset intensity, target & 0.338 & 0.826 & 0.000 & 15.60 \\
\hline Intangible asset intensity, acquirer & 0.442 & 0.938 & 0.000 & 15.38 \\
\hline Merger challenged & 0.064 & 0.255 & 0.000 & 1.000 \\
\hline Real exchange rate index, target country & 1.007 & 1.016 & 0.720 & 2.190 \\
\hline Population, target country (billions) & 0.135 & 0.182 & 0.000 & 1.338 \\
\hline Average tariff rate, target country & 0.041 & 0.013 & 0.000 & 0.291 \\
\hline Real exchange rate index, acquirer country & 0.993 & 0.089 & 0.011 & 1.260 \\
\hline Population, acquirer country (billions) & 0.114 & 0.188 & 0.000 & 1.338 \\
\hline Distance $(1,000 \mathrm{~km})$ & 4.834 & 4.551 & 0.012 & 19.14 \\
\hline Contiguous & 0.193 & 0.395 & 0.000 & 1.000 \\
\hline Common language & 0.374 & 0.484 & 0.000 & 1.000 \\
\hline Colonial relationship & 0.191 & 0.393 & 0.000 & 1.000 \\
\hline GP_index & 4.462 & 0.458 & 1.600 & 4.880 \\
\hline
\end{tabular}

significantly in the sample, to a high of over $1,200 \%$. The average level of percent ownership in the full-sample was $73.0 \%$, but ranged from a low of $0.3 \%$ to a high of $100 \%$. Over $40 \%$ of the mergers in our sample involved firms within the same industry. The summary statistics suggest that most cross-border mergers occur between firms with similar cultural backgrounds; $37 \%$ of the mergers in our sample involved firms from countries with the same primary language, and $20 \%$ involved firms from countries that shared a border.

Perhaps more interestingly, Table 4 presents the difference in summary statistics for those mergers involving firms in developing countries compared to those involving firms in industrialized countries. Although the average deal premium is statistically identical for deals involving industrialized targets when compared to targets in developing countries (34.8\% compared to $35.5 \%$ ), there are a number of statistical differences. For example, mergers with firms in industrialized countries involve a statistically higher ownership percentage when compared to deals involving firms in developing countries; on average acquiring firms took $77.8 \%$ ownership in mergers in industrialized countries compared to $42.4 \%$ ownership in mergers with firms in developing countries. Preliminary analysis of our data suggests that firms may be willing to pay more for control in developing countries when compared to industrialized countries. A scatterplot of the correlation between deal premium and percent ownership for our entire sample is presented in Fig. 3. The correlation between the two variables is 0.26 in mergers involving developing countries, but only 0.24 in mergers involving industrialized countries. Other key 
Table 4 Summary statistics by target type

\begin{tabular}{|c|c|c|c|c|}
\hline \multirow[t]{2}{*}{ Variable } & \multicolumn{2}{|c|}{ Industrialized targets } & \multicolumn{2}{|c|}{ Developing targets } \\
\hline & Mean & $\begin{array}{l}\text { Standard } \\
\text { deviation }\end{array}$ & Mean & $\begin{array}{l}\text { Standard } \\
\text { deviation }\end{array}$ \\
\hline Deal premium & 0.348 & 0.333 & 0.355 & 1.244 \\
\hline Related* & 0.411 & 0.492 & 0.614 & 0.489 \\
\hline Percent ownership* & 0.778 & 0.331 & 0.424 & 0.312 \\
\hline Deal value (billions)* & 2.522 & 5.181 & 1.242 & 1.404 \\
\hline Sales ratio & 1.109 & 10.21 & 0.398 & 1.627 \\
\hline Intangible asset intensity, target & 0.332 & 0.581 & 0.381 & 1.731 \\
\hline Intangible asset intensity, acquirer* & 0.473 & 0.997 & 0.245 & 0.346 \\
\hline Merger challenged & 0.068 & 0.252 & 0.043 & 0.205 \\
\hline Real exchange rate index, target country* & 0.998 & 0.079 & 1.007 & 0.193 \\
\hline Population, target country (billions) ${ }^{*}$ & 0.120 & 0.125 & 0.230 & 0.368 \\
\hline Average tariff rate, target country* & 0.032 & 0.016 & 0.100 & 0.046 \\
\hline Real exchange rate index, acquirer country & 0.991 & 0.088 & 1.000 & 0.097 \\
\hline Population, acquirer country (billions) & 0.115 & 0.187 & 0.109 & 0.195 \\
\hline Distance $(1,000 \mathrm{~km})^{*}$ & 4.740 & 4.620 & 5.461 & 4.050 \\
\hline Contiguous* & 0.204 & 0.404 & 0.122 & 0.329 \\
\hline Common language* & 0.398 & 0.489 & 0.219 & 0.415 \\
\hline Colonial relationship & 0.196 & 0.397 & 0.157 & 0.367 \\
\hline IPR index* & 4.590 & 0.011 & 3.646 & 0.048 \\
\hline
\end{tabular}

Starred variables are those in which there are significant differences to the $5 \%$ level in the sample means between mergers with firms in industrialized countries compared to those with firms in developing countries

differences in the summary statistics when comparing mergers involving industrialized targets to those involving developing countries include the fact that the average tariff rate is significantly higher in developing countries, and mergers involving firms from developing countries are on average between countries that are further apart.

\section{Results}

Table 5 shows the results from the regression analysis for the full sample in column 1 ; all continuous variables are measured in logs, thus the parameter estimates can be interpreted as elasticities. ${ }^{11}$ Not surprisingly given our summary statistics, we find that on average firms pay $0.6 \%$ less to acquire firms in developing countries. However, there is a positive and statistically significant impact of the percent

\footnotetext{
${ }^{11}$ The regressions exclude approximately 70 observations with missing explanatory variables, primarily exchange rate variables. Parameter estimates associated with our primary variables of interest were qualitatively the same when we run the regression on the full sample, excluding the exchange rate variables.
} 


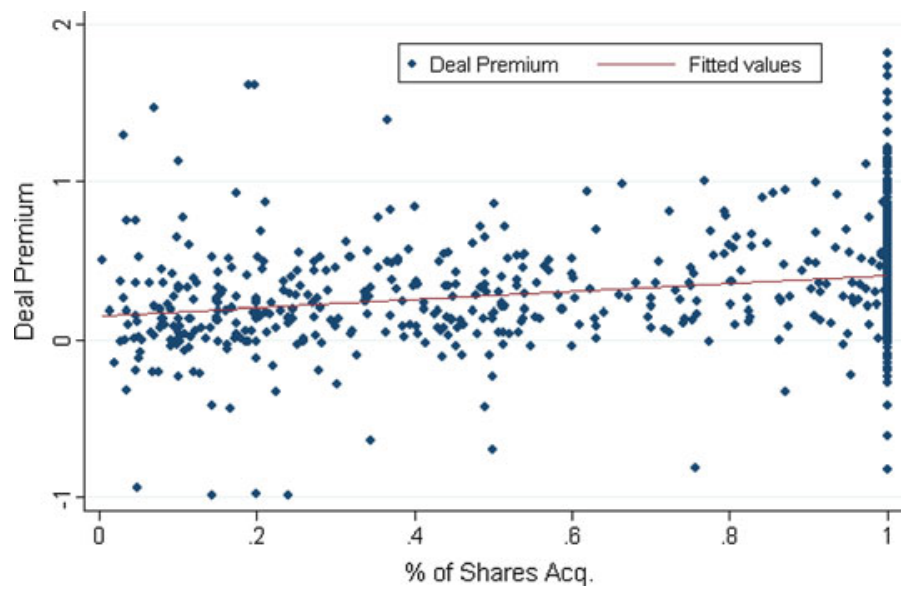

Fig. 3 Correlation between deal premium and ownership

ownership variable on the deal premium, indicating that firms are willing to pay more to gain greater control over a foreign firm's assets, and the value of this control is higher in developing countries. Specifically, we find a $1 \%$ increase in the percent ownership results in a $0.4 \%$ increase in the deal premium paid, while that same increase in percent ownership results in a $1.5 \%$ increase in the deal premium for mergers involving firms in developing countries.

A number of other variables that we hypothesized should be important to the expected value of a merger are statistically significant and of the hypothesized sign. For example, we find that firms pay on average $0.2 \%$ more in mergers that end up being challenged, suggesting that firms pay a higher premium to acquire firms when there are substantial, expected market power gains from the merger. ${ }^{12}$ Firms also pay more for firms as the exchange rate of the home country of the target appreciates, which is reflective of the fact that the price will be higher when converted back to the acquiring firm's home currency. ${ }^{13}$ Finally, we find that the deal premium falls with the size of the deal; for every $1 \%$ increase in the size of the purchase, the deal premium falls by $0.02 \%$.

Column 2 presents the same specification with the addition of two variables, intangible asset intensity of both the target and the acquiring firm. Note that the sample size is quite a bit smaller because this measure was not available for all of the firms in our sample; however, the results of our primary variables of interest, the percent ownership variables, are qualitatively the same, as are the elasticities

\footnotetext{
12 This result is consistent with the results in Sonenshine (2010), which analyzed large mergers of U.S. based companies.

13 As noted earlier, we also analyzed the results from sub-samples consisting of larger deals in order to evaluate how sensitive our results were to the $\$ 250$ million dollar cutoff. In these samples, the coefficient on the acquirer's real effective exchange rate was significant while the coefficient for the target's real effective exchange rate was not. It seems that for larger deals, acquirers are willing to pay higher premia when they have a stronger domestic currency. The results from the larger deal sub-samples are more consistent with results from Harris and Ravenscraft (1991) and Swenson (1993), both of which only looked at deals involving U.S. targets.
} 
Table 5 Regression results

\begin{tabular}{|c|c|c|c|c|}
\hline & (1) & (2) & (3) & (4) \\
\hline Percent ownership & $\begin{array}{l}0.363 * * * \\
(0.082)\end{array}$ & $\begin{array}{l}0.344 * * \\
(0.109)\end{array}$ & $\begin{array}{l}0.676^{* * * *} \\
(0.213)\end{array}$ & $\begin{array}{l}0.302 * * * \\
(0.097)\end{array}$ \\
\hline Target in developing country & $\begin{array}{l}-0.631 * * * \\
(0.134)\end{array}$ & $\begin{array}{l}-0.877 * * * \\
(0.191)\end{array}$ & $\begin{array}{l}-1.143^{* *} \\
(0.450)\end{array}$ & $\begin{array}{l}-0.687 * * * \\
(0.153)\end{array}$ \\
\hline Ownership $\times$ target in developing & $\begin{array}{l}1.103 * * * \\
(0.245)\end{array}$ & $\begin{array}{l}1.579 * * * \\
(0.364)\end{array}$ & $\begin{array}{l}2.178 * * * \\
(0.774)\end{array}$ & $\begin{array}{l}0.986 * * * \\
(0.289)\end{array}$ \\
\hline Related & $\begin{array}{l}-0.011 \\
(0.033)\end{array}$ & $\begin{array}{l}-0.014 \\
(0.044)\end{array}$ & $\begin{array}{l}-0.010 \\
(0.084)\end{array}$ & $\begin{array}{l}-0.000 \\
(0.040)\end{array}$ \\
\hline Deal value & $\begin{array}{l}-0.027 * * \\
(0.015)\end{array}$ & $\begin{array}{l}-0.025 \\
(0.019)\end{array}$ & $\begin{array}{l}-0.018 \\
(0.037)\end{array}$ & $\begin{array}{l}-0.019 \\
(0.017)\end{array}$ \\
\hline Sales ratio & $\begin{array}{l}-0.039 \\
(0.038)\end{array}$ & $\begin{array}{l}-0.038 \\
(0.068)\end{array}$ & $\begin{array}{l}-0.051 \\
(0.114)\end{array}$ & $\begin{array}{l}-0.049 \\
(0.071)\end{array}$ \\
\hline Challenged & $\begin{array}{l}0.179 * * * \\
(0.066)\end{array}$ & $\begin{array}{l}0.207 * * * \\
(0.087)\end{array}$ & $\begin{array}{l}0.121 \\
(0.156)\end{array}$ & $\begin{array}{l}0.162 * * * \\
(0.080)\end{array}$ \\
\hline Real exchange rate index, target & $\begin{array}{l}0.631 * * * \\
(0.177)\end{array}$ & $\begin{array}{l}0.806 * * * \\
(0.238)\end{array}$ & $\begin{array}{l}1.702 * * * \\
(0.399)\end{array}$ & $\begin{array}{l}0.226 \\
(0.226)\end{array}$ \\
\hline Real exchange rate index, acquirer & $\begin{array}{l}0.022 \\
(0.088)\end{array}$ & $\begin{array}{l}0.266 \\
(0.271)\end{array}$ & $\begin{array}{l}0.725 \\
(0.573)\end{array}$ & $\begin{array}{l}-0.020 \\
(0.088)\end{array}$ \\
\hline Population, target & $\begin{array}{l}0.006 \\
(0.013)\end{array}$ & $\begin{array}{l}0.012 \\
(0.018)\end{array}$ & $\begin{array}{l}-0.018 \\
(0.038)\end{array}$ & $\begin{array}{l}0.013 \\
(0.016)\end{array}$ \\
\hline Average tariff rate, target & $\begin{array}{l}-1.001 \\
(1.091)\end{array}$ & $\begin{array}{l}-0.368 \\
(1.577)\end{array}$ & $\begin{array}{l}-6.089 * * \\
(3.041)\end{array}$ & $\begin{array}{l}1.789 \\
(1.304)\end{array}$ \\
\hline Distance & $\begin{array}{l}-0.009 \\
(0.012)\end{array}$ & $\begin{array}{l}-0.020 \\
(0.017)\end{array}$ & $\begin{array}{l}0.002 \\
(0.036)\end{array}$ & $\begin{array}{l}-0.002 \\
(0.014)\end{array}$ \\
\hline IP index & $\begin{array}{l}-0.238 \\
(0.241)\end{array}$ & $\begin{array}{l}-0.152 \\
(0.320)\end{array}$ & $\begin{array}{l}-0.991 \\
(0.746)\end{array}$ & $\begin{array}{l}-0.338 \\
(0.274)\end{array}$ \\
\hline Intangible asset, target & & $\begin{array}{l}0.005 \\
(0.013)\end{array}$ & & \\
\hline Intangible assets, acquirer & & $\begin{array}{l}-0.000 \\
(0.014)\end{array}$ & & \\
\hline Year dummies & Yes & Yes & Yes & Yes \\
\hline No. of observations & 775 & 553 & 173 & 501 \\
\hline Adjusted $\mathrm{R}^{2}$ & 0.136 & 0.151 & 0.376 & 0.139 \\
\hline
\end{tabular}

Robust standard errors are in parentheses

$M S E$ means square error

$* * *, * *, *$ Statistical significance levels of 1,5 , and $10 \%$ respectively

associated with the other statistically significant variables discussed above. Neither of the coefficients for the intangible asset variables had a statistically significant effect on the deal premium. 
Table 6 Average merger premia-high versus low intangible asset intensity premia (observations in parentheses)

\begin{tabular}{llll}
\hline Acquirer type & $\begin{array}{l}\text { High } \\
\text { intangible } \\
\text { intensity }\end{array}$ & $\begin{array}{l}\text { Low } \\
\text { intangible } \\
\text { intensity }\end{array}$ & Total \\
\hline Developed & $37 \%(272)$ & $33(462)$ & $35 \%(734)$ \\
Developing & $68 \%(30)$ & $23 \%(84)$ & $36 \%(114)$ \\
Total & $40 \%(302)$ & $31 \%(546)$ & $35 \%(848)$ \\
\hline
\end{tabular}

We next investigate why the ownership premium might be higher in developing economies. As mentioned earlier, Moran (2001) and others found that gaining ownership control was valuable when the firms had relatively high intangible asset intensity levels. As such, we considered whether there are differences in the deal premia paid in cross-border mergers based on the intangible asset intensity of the acquirer. We hypothesize that acquirers with a high value of intangible assets place greater importance on ownership in countries where writing or enforcing contracts may be difficult, and it is harder to protect these intangible assets, as may be the case in emerging markets. If this is the case, we would not necessarily expect to find ownership valued more in developing countries by acquirers with relatively low intangible asset intensity.

To test this hypothesis, we separated the sample into high and low acquirer intangible asset intensity, where high intangible asset firms are those with intangible asset shares in the top $25 \%$ of the sample. The average deal premia in these two samples are shown in Table 6. Here, we see firms with greater intangible asset intensities pay on average a higher premium for their acquisitions, and the difference is particularly stark when the target resides in a developing country.

Regressions for each segment (high and low intangible asset intensity acquirers) are presented in Table 5; column 3 includes results for acquiring firms with high intangible assets and column 4 shows results for acquiring firms with relatively low intangible asset intensity. In comparing the results of the two columns, we find the coefficient for the target being in a developing country to be negative and significant in both samples while the coefficients for the percent of ownership and ownership in developing countries are positive and significant. However, the coefficients for these three variables are roughly twice as large for the high acquirer intensity sample, indicating that ownership overall and ownership in developing countries has a larger impact on the premia paid by high versus low intangible asset intensity acquirers. ${ }^{14}$

There are some other notable differences between the results from the two samples. Although the coefficient associated with the target's real exchange rate is positive and significant in the high intangible asset intensity sample, this explanatory variable has no statistically significant impact on the deal premia in

\footnotetext{
${ }^{14}$ We also ran this model by interacting a continuous measure of intangible asset intensity with the key explanatory variables. None of the interaction terms proved to be significant, although the coefficients from a model interacting a dummy variable for high intangible asset firms with our key variables of interest were qualitatively identical to those presented here. This suggests that while ownership is more important to firms with large values of intangible assets, this value of ownership does not increase for marginal increases in intangible asset intensity. The results from these specifications are available from the authors upon request.
} 
mergers involving firms with lower levels of intangible assets. Similarly, the average tariff rate in the target country has a negative and significant impact on the deal premia in the high intangible asset intensity sample, but not in the low intangible asset intensity sample. As noted previously, it is not surprising that the coefficient for the target's real exchange is positive and significant as acquirers take advantage of a depreciating real exchange rate to offer a higher premium.

We were surprised to find that firms place less value on firms in countries with higher average tariff rates. Intuitively, one might expect firms to be willing to pay more to purchase a firm that would give them access to a market protected behind high tariff barriers. Instead, we find that high intangible asset intensity acquirers place lower premia on targets from countries with high tariff barriers. We surmise that deal premia are negatively impacted by high tariff barriers because the countries with high levels of protectionism are also the ones where it is more difficult to do business. In reviewing the data set, we see that Egypt, India, Brazil, Mexico, and Bermuda were the countries with the highest tariff rates. Each of these countries ranked among the hardest countries to do business in the World Bank's Ease of Doing Business Index. ${ }^{15}$

Another intriguing finding is that the coefficients for these variables (average tariff rates and real effective exchange rate) are not significant in the low acquirer intangible asset intensity sample. It may be that acquirers are not able to pass through exchange rate or tax changes into the deal premia when acquiring firms with low intangible asset intensity levels. Instead, synergies for low intangible asset intensity firms in cross-border mergers are affected by ownership control, as noted earlier, and other industry-specific factors outside the model, which is why the R-squared for this sample is low. We do see in column 4 that the coefficient for the merger challenge is positive and significant indicating that firms will pay more for a merger that results in higher levels of market power. It seems that acquirers whose assets are largely tangible may gain more from the potential pricing power that may result from a challenged merger than acquirers with higher intangible asset intensity levels. It is important to note that almost all of the targets in the challenged mergers reside in developed countries.

Finally, we find that industry relatedness does not have a significant effect on the premia paid. Our results contradict the findings in Marr et al. (2006), which showed industry relatedness to have a positive, significant effect on shareholder value. Given that Marr et al. (2006) solely analyzed takeovers of U.S. firms, the differences can undoubtedly be attributed to differences in the sample of mergers.

In summary, the importance of ownership in cross-border mergers differs based on the intangible asset intensity of the acquirer. With higher levels of intangible asset intensity, gaining ownership control has a large significant effect on the deal premium. Other factors, such as tariffs and the real exchange rate, also have a significant impact on the deal premium paid by acquirers with high levels of

\footnotetext{
15 The World Bank ranks countries each year based on how conducive the regulatory environment is to starting and operating a local firm. India, Brazil, and Egypt were ranked 132, 126, and 110 in the World Bank's 2012 Ease of Doing Business ranking. India had the second worst ranking among the countries in our data set; Brazil the fourth worse, and Egypt the seventh worst.
} 
intangible assets. Ownership is significant but does not have as strong an effect for acquirers with lower levels of intangible assets.

\section{Conclusions}

This study examines differences between the deal premia paid to effectuate a crossborder merger. Consistent with other studies, we found ownership percentage to have a positive effect on the deal premium and the effect is greatest when the target is in an emerging market. We also find differences in some of the factors that affect the deal premium when the sample is segmented into high and low intangible asset intensity acquirers. Although firms in both samples are willing to pay an increasing amount to acquire more control over their acquisition, especially in developing countries, ownership appears to be more important to firms with higher levels of intangible assets. Acquirers with high levels of intangible asset intensity also pay significantly more for firms in countries with lower tariff rates and higher real effective exchange rates. In contrast, acquirers with lower levels of intangible asset intensity pay more to acquire firms that are expected to result in significant pricing power.

The study is broad in covering all cross-border mergers among firms over an eleven year time period provided the transaction value was over $\$ 250$ million. It is left to other research to study cross-border mergers among specific pairings of countries or in geographic or industry segments. Another avenue of research is to analyze the factors that influence the decision to engage in other forms of FDI.

\section{References}

Buckley, P. J., \& Casson, M. C. (1976). The future of the multinational enterprise. London: The MacMillan Press.

Caves, R. E. (1982). Multinational enterprise and economic analysis. Cambridge, New York: Cambridge University Press.

Cebenoyan, S., Papaioannou, G., \& Travlos, N. (1992). Foreign takeover activity in the U.S. and wealth effects for target firm shareholders. Financial Management, 21(3), 58-68.

Chari, A., Ouimet, P., \& Tesar, L. (2010). The value of control in emerging markets. The Review of Financial Studies, 23(4), 1741-1770.

Coase, R. (1937). The nature of the firm. Economica, 4(16), 386-405.

Datta, D., \& Puia, G. (1995). Cross-border acquisitions: An examination of the influence of relatedness and cultural fit on shareholder value creation in U.S. acquiring firms. Management International Review, 35(4), 337-359.

Dewenter, K. (1995). Do exchange rate changes drive foreign direct investment? Journal of Business, 68(3), 405-433.

Dunning, J., \& Rugman, A. (1985). The influence of Hymer's dissertation on the theory of foreign direct. American Economic Review, 75(2), 228-232.

Froot, K. A., \& Stein, J. C. (1991). Exchange rates and foreign direct investment: An imperfect capital markets approach. Quarterly Journal of Economics, 106, 1191-1217.

Grossman, S., \& Hart, O. (1986). The costs and benefits of ownership: A theory of vertical and lateral integration. Journal of Political Economy, 94(4), 691-719. 
Harris, R. S., \& Ravenscraft, D. (1991). The role of acquisitions in foreign direct investment: Evidence from the U.S. stock market. Journal of Finance, 46, 825-844.

Hymer, S. H. (1960). The international operations of national firms: A study of direct foreign investment. Cambridge: MIT Press.

Kindleberger, C. P. (1984). Multinational excursions. Cambridge: MIT Press.

Klein, B., Crawford, R. G., \& Alchian, A. A. (1978). Vertical integration, appropriable rents, and the competitive contracting process. The Journal of Law \& Economics, 21(2), 297-326.

Kuipers, D., Miller, D., \& Patel, A. (2009). The legal environment and corporate valuation: Evidence from cross-border takeovers. International Review of Economics and Finance, 18(4), 552-567.

Magee, S. P. (1976). Technology and the appropriability theory of the multinational corporation. In J. Bhajwati (Ed.), The new international economic order. Cambridge, MA: MIT Press.

Markides, C., \& Ittner, C. (1994). Shareholder benefits from corporate international diversification: evidence from US international acquisitions. Journal of International Business Studies, 25(2), 343-366.

Marr, W., Mohta, S., \& Spivey, M. (2006). An analysis of foreign takeovers in the United States. Managerial and Decision Economics, 14(4), 285-294.

Moran, T. (2001). Parental supervision: The New paradigm for foreign direct investment and development. Washington, DC: Institute of International Economics.

Morck, R., \& Yeung, B. (1992). Internalization: An event study test. Journal of International Economics, 33(1-2), 41-56.

Newburry, W., \& Zeira, Y. (1997). Generic differences between equity international joint ventures (EIJVs), international acquisitions (IAs), and international Greenfield investments (IGIs): Implications for parent companies. Journal of World Business, 32(2), 87-102.

OECD (Organization for Economic Coooperation and Development) Development Centre. (2010). Shifting wealth. Paris, France: Perspectives on Global Development.

Park, W. (2008). International patent protection: 1960-2005. Research Policy, 37(4), 761-766.

Shimizu, K., Hitt, M., Vaidyanath, D., \& Pisano, D. (2004). Theoretical foundations for cross-border mergers and acquisitions: A review of current research and recommendations for the future. Journal of International Management, 10(3), 307-353.

Sonenshine, R. (2010). The stock market value of R\&D and market concentration in horizontal mergers. Review of Industrial Organization, 37(2), 119-140.

Swenson, D. L. (1993). Foreign mergers and acquisitions in the United States. In K. A. Froot (Ed.), Foreign direct investment (pp. 255-281). Chicago: University of Chicago Press.

Vermuelen, F., \& Barkema, H. (2001). Learning through acquisitions. Academy of Management Journal, 44(3), 457-476.

Vernon, R. (1966). International investment and international trade in the product cycle. Quarterly Journal of Economics, 80(2), 190-207.

Weitzel, U., \& Berns, S. (2006). Cross-border takeovers, corruption, and related aspects of governance. Journal of International Business Studies, 37(60), 786-806.

Williamson, O. E. (1979). Transaction-cost economics: The governance of contractual relations. Journal of Law and Economics, 22(2), 233-261. 